\title{
Assessment of Entomological Remains from Soil Samples Collected from a Pig (Sus scrofa domestica) Carcass Decomposition Site after 13 Years
}

\author{
On Üç Yil Sonra Domuz Leşinin (Sus scrofa domestica) Dekompozisyon Bölgesinden \\ Toplanan Toprak Örneklerindeki Entomolojik Kalıntlların Değerlendirilmesi
}

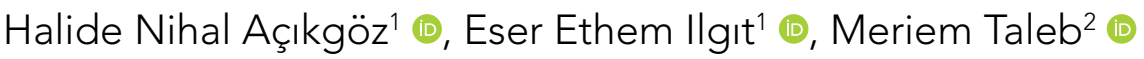

${ }^{1}$ Ankara University Institute of Forensic Sciences, Ankara, Turkey

2University of Blida, Laboratory of Biotechnologies, Environment and Health, Faculty of Nature and Life Sciences, Blida, Algeria

Cite this article as: Açıkgöz HN, llgıt EE, Taleb M. Assessment of Entomological Remains From Soil Samples Collected From a Pig (Sus scrofa domestica) Carcass Decomposition Site After 13 Years. Turkiye Parazitol Derg 2018; 42(4): 281-5.

\section{ABSTRACT}

Objective: Carrion insects inhabiting the soil play an important role in forensic investigations because they may help to solve both active and cold cases. The aim of this study was to examine the entomofauna of forensic importance in soil samples removed after 13 years from a pig carrion decomposition site.

Methods: Soil samples were collected from an old carrion decomposition study site in Bâla, the Ankara Province. Four holes, approximately $40 \mathrm{~cm}$ deep and $35 \mathrm{~cm}$ width were excavated at the study site. The samples were collected and placed in ventilated cups. Each cup was labeled mentioning the excavation location, time, date, and name of the collector. Insects and their remains found in the soil were collected by sweeping the soil from the specimens using a brush. The insects were morphologically identified.

Results: A total of 635 specimens of Calliphoridae, Dermestidae, Cleridae, Staphylinidae, Histeridae, and Formicidae were identified. Flies such as Chrysomya albiceps (Wiedmann, 1819), and beetles such as Dermestes frischii (Kugelan, 1792), Necrobia rufipes (De Geer, 1775), and Creophilus maxillosus (Linnaeus, 1758), were identified as the species.

Conclusion: Our results show that soil samples still harbor entomological specimens after 13 years. This study, to the best of our knowledge, was the first of its kind in Turkey. Forensically, important insects and their remains may be identified in the soil long time after the corpse is buried. Consequently, cold cases may be solved using insects.

Keywords: Carcass, decomposition, entomofauna, forensic entomology, soil

Received: 06.03.2018

Accepted: 24.04 .2018

Available Online Date: 24.09 .2018

\section{Öz}

Amaç: Toprakta yaşayan böcekler, aktif ve eski olguların çözülmesine yardımcı olabileceğinden, adli araştırmalarda önemli rol oynamaktadır. Bu çalışmanın amacı, domuzun ölümünden 13 yıl sonra toprak örneklerinden çıkartılan adli önemi olan entomofaunayı incelemektir.

Yöntemler: Ankara ili Bâla ilçesinde on üç yıl önce ölen bir domuz leşi dekompozisyon çalışması alanından toprak örnekleri toplandı. Çalışma alanında yaklaşık $40 \mathrm{~cm}$ derinliğinde $35 \mathrm{~cm}$ genişliğinde 4 geniş delik kazıldı. Numuneler toplandı ve havalandırmalı bardaklara yerleştirildi. Her bardağın üzerine yer, saat, tarih ve toplayanın adı yazıldı. Topraktaki böcekler ve kalıntıları mikroskop altında toprağın bir fırça yardımıyla süpürülmesi ile toplandı ve morfolojik olarak tür tayini yapıldı.

Bulgular: Calliphoridae, Dermestidae, Cleridae, Staphylinidae, Histeridae ve Formicidae familyasına ait toplam 635 örnek tespit edildi. Sineklerden Chrysomya albiceps (Wiedmann, 1819), ve kınkanatlılardan ise Dermestes frischii (Kugelan, 1792), Necrobia rufipes (De Geer, 1775) ile Creophilus maxillosus (Linnaeus, 1758) türleri teşhis edildi.

Sonuç: Bu bulgular, on üç yıl sonra hala toprak numunelerinin entomolojik örnekleri barındırdığını göstermiştir. Sunulan çalışma Türkiyede ilk kez yapılmıştır. Sonuç olarak, adli önemi olan böceklerin ve kalıntılarının, ölüm yerinin toprağından uzun süre sonra bile tespit edilebildiğini ve aynı zamanda çözülememiş eski adli vakaların da böceklerden yararlanılarak çözülebileceğini göstermiştir.

Anahtar Kelimeler: Ceset, dekomposizyon, entomofauna, adli entomoloji, toprak

Geliş Tarihi: 06.03.2018

Kabul Tarihi: 24.04 .2018

Çevrimiçi Yayın Tarihi: 24.09.2018

$5^{\text {th }}$ EUROSOIL International Congress, Istanbul, TURKEY. 16.10.2016-21.10.2016.

5. Ulusalarası katılımlı avrupa toprak kongresi, Istanbul, TÜRKIYE 16.10.2016-21.10.2016.

Address for Correspondence / Yazışma Adresi: Halide Nihal Açıkgöz E.posta: nacikgoz@yahoo.com DOI: $10.5152 /$ tpd.2018.5917

(C) Copyright 2018 Turkish Society for Parasitology - Available online at www.turkiyeparazitolderg.org

OTelif hakkı 2018 Türkiye Parazitoloji Derneği - Makale metnine www.turkiyeparazitolderg.org web sayfasından ulaşılabilir. 


\section{INTRODUCTION}

Forensic entomology is the study of the arthropod development and colonization of corpses in the succession pattern to solve legal cases (1-3). It is commonly used to estimate the time between death and the corpse discovery. This period is called the postmortem interval (PMI) (4). When this interval is greater than 72 hours, forensic entomology methods can be more accurate in estimating the PMI than traditional medical techniques, and sometimes they are the only available techniques (4-6). After death, the odor emitted by the carcass attracts different insect species. Flies (Diptera) and beetles (Coleoptera) are the first to reach the carcass and are the most common species. Among dipteran species, blowflies (Diptera: Calliphoridae) are the initial colonizers of dead bodies (6-9). Arthropods associated with a carcass are generally classified into four ecological categories: necrophages, parasites and predators of the necrophages, omnivores, and adventive species (7). Arnaldos et al. (10) reported that the Formicidae species use the body as a shelter to obtain humidity and food and that they may be considered omnivorous. The Formicidae species belong mainly to the local fauna and may be present even before the body placement. Thus, these species are of lesser forensic importance than the necrophagous ones.

Body decomposition in a terrestrial environment alters the substrate beneath (11). This initiates a series of changes in vegetation and fauna, beginning a succession of arthropods affected by the carcass decomposition. Fluids that are a product of decomposition and associated carcass fauna are reported to change the soil to a depth of $14 \mathrm{~cm}$, affecting mostly the upper layers. The soil that is directly beneath and surrounding the body represents a decompositional zone occupied by the carcass dwellers distinct from a surrounding area of approximately $10 \mathrm{~cm}$. This provides an intermediate zone inhabited by both the carrion and regular soil-dwelling invertebrates (12).

Insects found on buried bodies in the soil for a short or long period are of a great forensic interest. Some arthropod species associated with decomposing bodies are not found on the re-

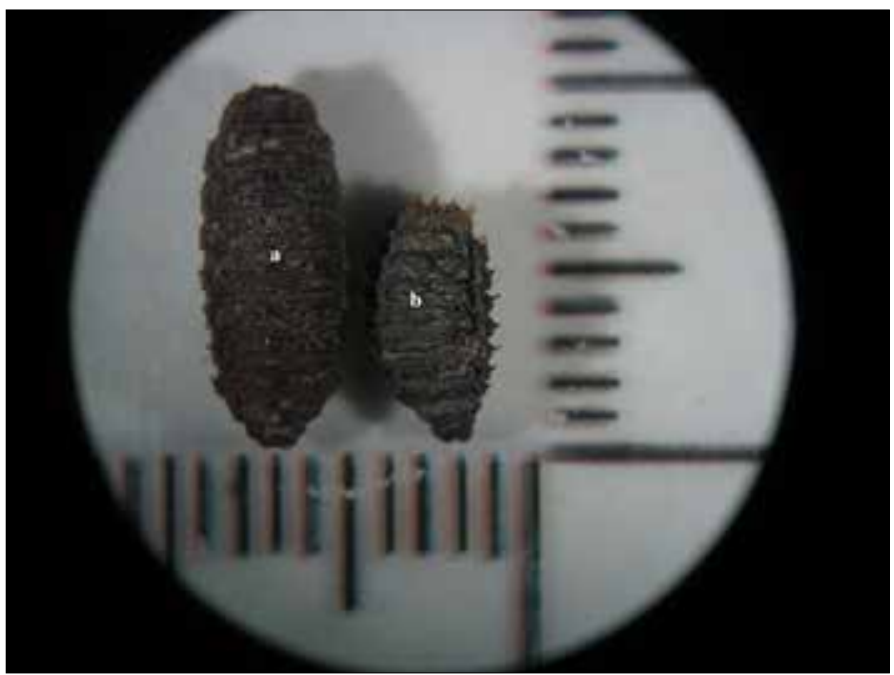

Figure 1. Diptera Pupae. A: Chrysomya albiceps pupa; B: Fannidae sp. pupa. mains, but are distributed around, or even inhabiting the soil under the body. It is thus possible to prove whether the dead body was moved or not after death and to determine the primary and secondary crime scenes. Therefore, it is crucial to collect soil samples during criminal investigations (12).

In this context, the aim of this study was to examine the entomofauna of forensic importance in soil samples 13 years after death

\section{METHODS}

\section{The Study Area}

A field trial with a decomposing carcass of a pig (Sus scrofa domestica) was conducted in Çavuşlu, Bâla, Ankara (3940'59.0"N $\left.33^{\circ} 00^{\prime} 13.1^{\prime \prime} \mathrm{E}\right)$ during the years from 2003 to 2005. In January 2016, four holes, approximately $40 \mathrm{~cm}$ deep were excavated at the study site. The buried pig skeleton was found. The soil samples were collected and placed in polystyrene disposable cups. Each cup was labeled mentioning the excavation location, time, and date.

The collected samples were transferred to the Forensic Sciences Institute of Ankara University and examined under a Leica S8 APO stereo zoom microscope.

\section{Laboratory Study}

The soil was dried on a sheet of paper in the laboratory. Insects and their remains found in the soil were collected by sweeping the soil from the specimens using a brush. They were then photographed (Canon PowerShot S60) (Figures 1-6) and morphologically identified using standard taxonomic keys $(13,14)$.

\section{RESULTS}

In this study, we describe the entomofauna of forensic interest found in the soil samples recovered from an old decomposition study's location. A total number of 635 specimens of Calliphoridae, Dermestidae, Cleridae, Staphylinidae, Histeridae, and Formicidae were found. The identification results of insect species and their numbers are presented in Table 1. We noticed that the soil samples were still harboring entomological spec-

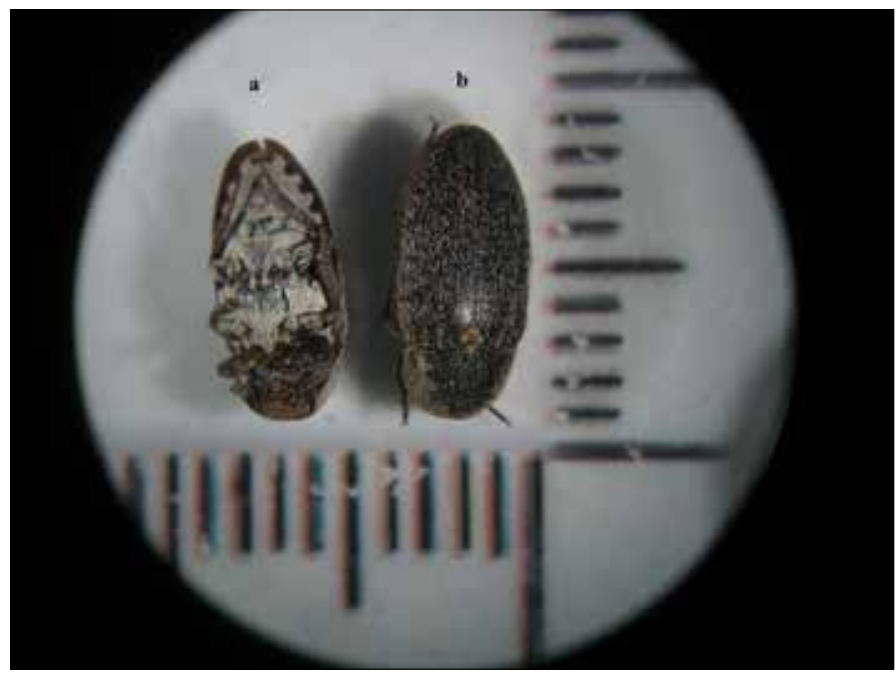

Figure 2. Dermestes frischii adult. A: ventral view; B: dorsal view. 


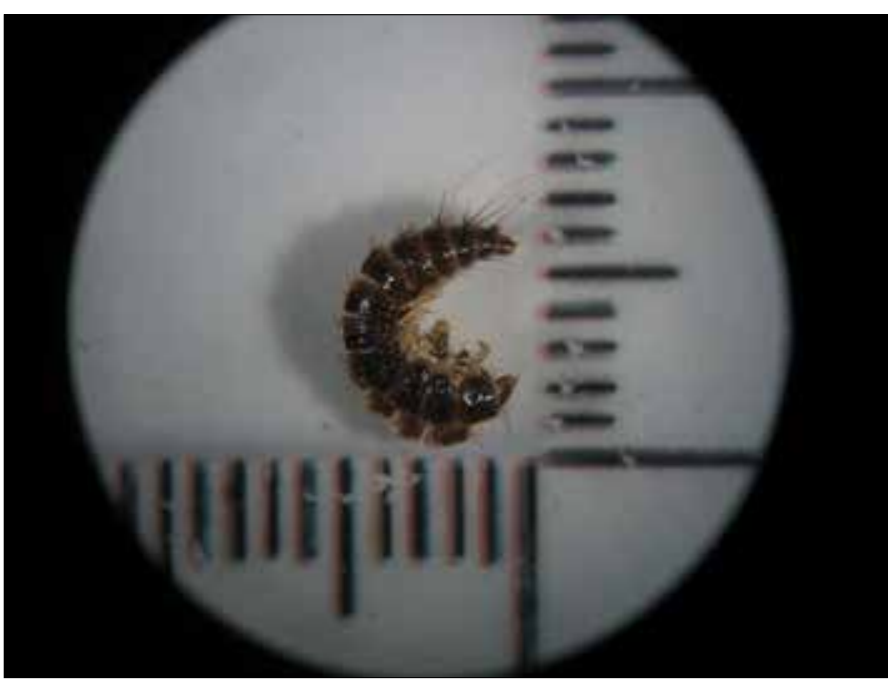

Figure 3. Dermestes sp. larva.

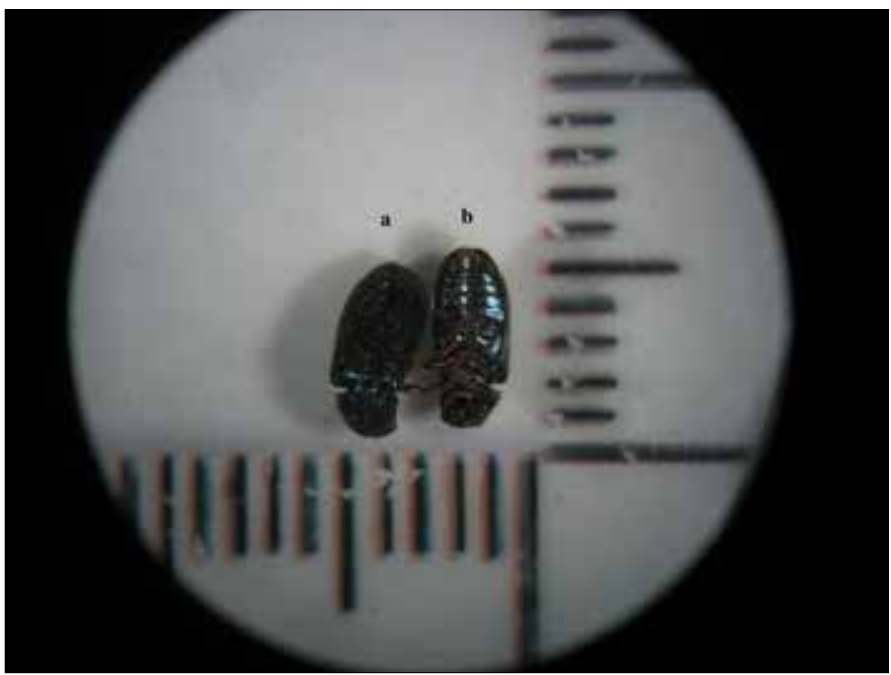

Figure 4. Necrobia rufipes adult. A: dorsal view B: ventral view.

imens after 13 years. Overall, 28.2\% of the of the specimens were identified at the species level, and they included Chrysomya albiceps (Wiedmann, 1819), Dermestes frischii (Kugelan, 1792), Necrobia rufipes (De Geer, 1775), and Creophilus maxillosus (Linnaeus, 1758).

\section{DISCUSSION}

Necrobia rufipes is a slow-developing species depending on temperature. It is known to be the predator of other insects and cannibal in the presence of other species in large numbers. This predatory behavior also occurs in the third larvar instar of the Chrysomya albiceps species $(9,15,16)$. Creophilus maxillosus is a scavenger and can be found on carcasses, and it is also the predator of carrion maggots (17-19). This predatory behavior is observed when the large numbers of Diptera larvae are present in the soil. Dermestes frischii is a species widely distributed all over the world. It is usually found in dry fish and legumes. Lefebvre and Gaudry (20) report that the dermestids arrive to animal carcasses in the third wave, during the advanced decay stage.

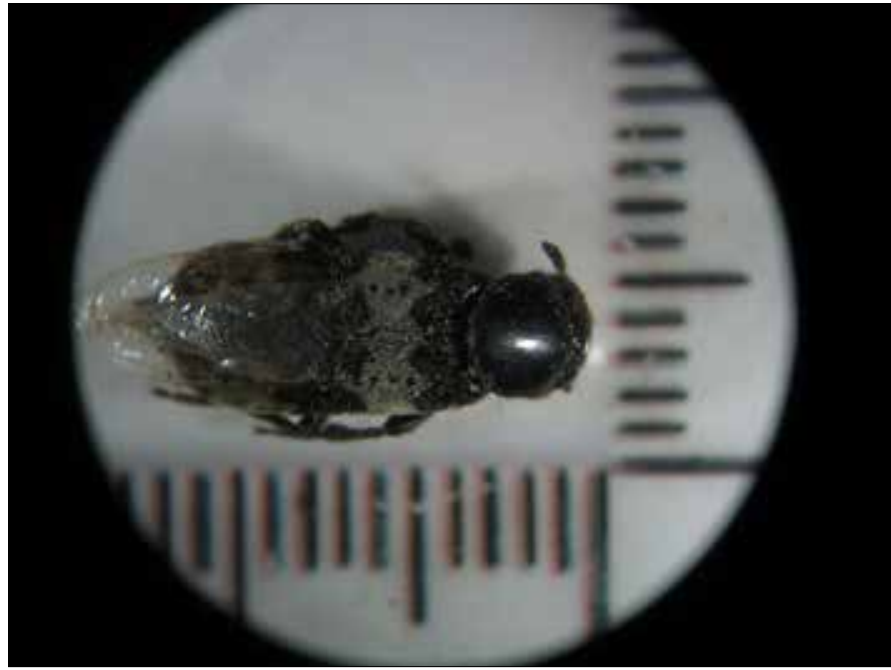

Figure 5. Creophilus maxillosus adult.

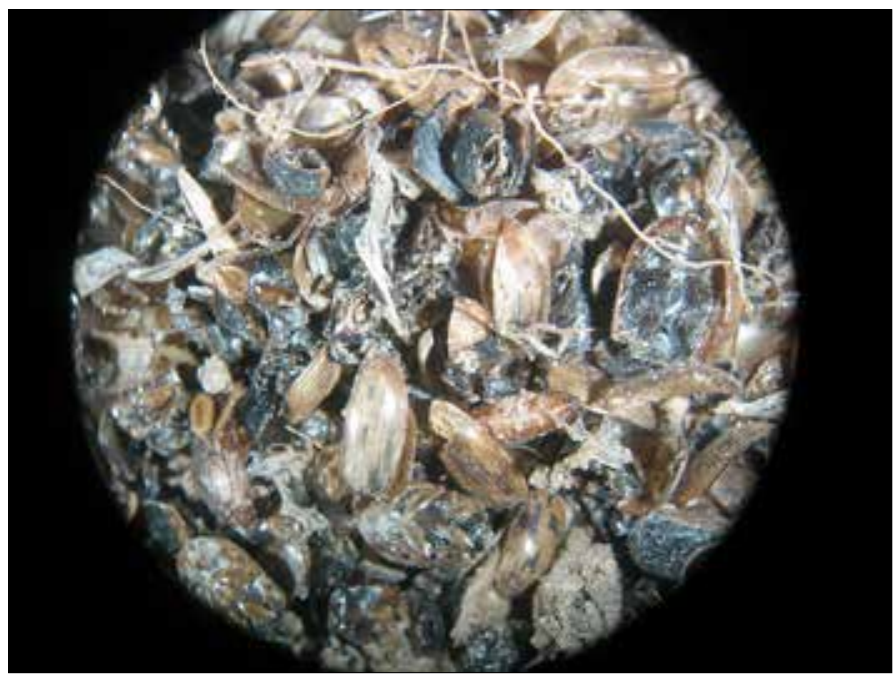

Figure 6. Coleoptera elytra.

Carter and Tibbett (21) state that the soil is a passive environment, influenced by the surroundings. Animal carcasses and plant cover mixed into the soil cause chemical and microbiological disturbances in the soil structure. The return of the original soil structure takes a long time (21). These findings support our results as the soil preserved the specimens for years. It might not have been possible to recover the samples in case of the lack of information about the body's site. At a depth of 40 $\mathrm{cm}$, some of the specimens were found buried in the soil due to rainfall and soil accumulation. Merritt et al. (22) discovered many arthropods in a grave opened 28 years after death. Some of them were reported to be Collembola (springtails), Acarina (mites) from the Glycyphagidae family, and Diptera pupae of the Phoridae family. Anderson and van Laerhoven (23) likewise stated that even 271 days after death, the vegetation and soil fauna had not returned to normal. Our results are in agreement with these findings. Based on these observations, it may be proved that a body was removed from its original location when necrophagous insects or their remains are not found in the soil samples. 
Table 1. Insect species and their remains identified from the soil samples.

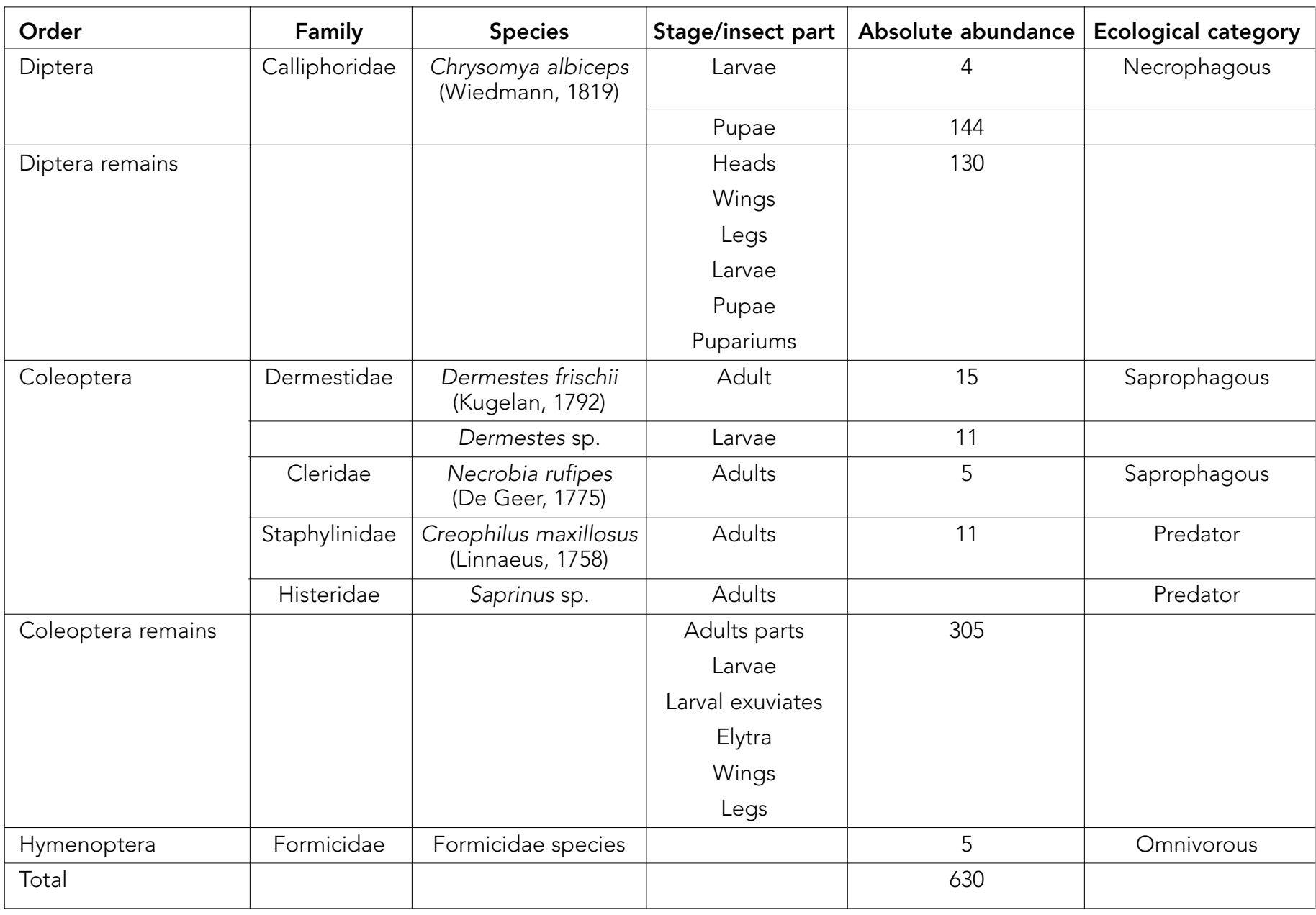

\section{CONCLUSION}

It is mandatory to collect soil to solve active and cold forensic cases. Insects of forensic interest and their remains can be identified from the soil long time after death. This practice may contribute greatly when determining whether a dumped body was shredded by scavenger vertebrates or removed from its original place.

Peer-review: Externally peer-reviewed.

Author Contributions: Concept - H.N.A.; Design - H.N.A., M.T.; Supervision - H.N.A.; Resources - H.N.A., M.T.; Materials - H.N.A.; Data Collection and/or Processing - H.N.A.; Analysis and/or Interpretation - H.N.A., M.T.; Literature Search - H.N.A., M.T.; Writing Manuscript - H.N.A., M.T., E.E.I.; Critical Review - H.N.A., M.T.

Conflict of Interest: Authors have no conflicts of interest to declare.

Financial Disclosure: The authors declared that this study has received no financial support.

Hakem Değerlendirmesi: Dış bağımsız.

Yazar Katkıları: Fikir - H.N.A.; Tasarım - H.N.A., M.T.; Denetleme H.N.A.; Kaynaklar - H.N.A., M.T.; Malzemeler - H.N.A.; Veri Toplanması ve/veya İşlemesi - H.N.A.; Analiz ve/veya Yorum - H.N.A., M.T.; Literatür Taraması - H.N.A., M.T.; Yazıyı Yazan - H.N.A., M.T., E.E.I.; Eleştirel İnceleme-H.N.A., M.T.

Çıkar Çatışması: Yazarlar çıkar çatışması bildirmemişlerdir.

Finansal Destek: Yazarlar bu çalışma için finansal destek almadıklarını beyan etmişlerdir.

\section{REFERENCES}

1. Catts $E$, Haskell N. Analyzing entomological data. In: Catts E, Haskell N, editors. Entomology and Death - A Procedural Guide. Clemson, South Carolina: Joyce's Print Shop; 1990. p. 125.

2. Wells JD, Lamotte L. The Role of a PMI-Prediction Model in Evaluating Forensic Entomology Experimental Design, the Importance of Covariates, and the Utility of Response Variables for Estimating Time Since Death. Insects 2017; 8: 47. [CrossRef]

3. Verma K, Reject P. Assessment of post mortem interval, (PMI) from forensic entomotoxicological studies of larvae and flies. Entomol Ornithol Herpetol 2013; 1: 1-4.

4. Joseph I, Mathew DG, Sathyan P, Vargheese G. The use of insects in forensic investigations: An overview on the scope of forensic entomology. J Forensic Dent Sci 2011; 3: 89-91. [CrossRef]

5. Sharma R, Kumar Garg R, Gaur JR. Various methods for the estimation of the post mortem interval from Calliphoridae: A review. Egypt J Forensic Sci 2015; 5: 1-12. [CrossRef] 
6. Amendt J, Richards C, Campobasso C, Zehner R, Hall M. Forensic entomology: applications and limitations. Forensic Sci Med Pathol 2011; 7: 379-92. [CrossRef]

7. Gennard D. Forensic Entomology: An Inroduction. West Sussex, UK: John Wiley \& Sons, Ltd.; 2012.

8. Brooks JW. Postmortem changes in animal carcasses and estimation of the postmortem interval. Vet Pathol 2016; 53: 929-40. [CrossRef]

9. Klekovska D, Slavevska-Stamenković V, Smiljkov S, Hinić J, Rebok K, Janeska B. Forensic use of Chrysomya albiceps (Wiedemann, 1819): the first cases indicating postmortem interval for human corpses in Republic of Macedonia. Journal of Entomology and Zoology Studies 2017; 5: 320-3.

10. Arnaldos MI, García MD, Romera E, Presa JJ, Luna A. Estimation of postmortem interval in real cases based on experimentally obtained entomological evidence. Forensic Sci Int 2005; 149: 57-65. [CrossRef]

11. Tibbett M, Carter D. Soil analysis in Forensic Taphonomy chemical and biological effects of buried human remains: CRC Press; 2008. [CrossRef]

12. Pastula E, Merritt R. Insect arrival pattern and succession on buried carrion in Michigan. J Med Entomol 2013; 50: 432-9. [CrossRef]

13. Smith K. A manual of forensic entomology. Oxford: University Printing House; 1986. 1-102 p.

14. Auber L. Atlas des coléoptères de France, Belgique, Suisse. Tome 1, Généralités, carabes, staphylins, dytiques, scarabées. Paris: N. Boubée; 1999.

15. Gredilha R, Lima A. First record of Necrobia rufipes (De Geer, 1775) (Coleoptera; Cleridae) associated with pet food in Brazil. Braz J Biol 2007; 67: 187. [CrossRef]
16. Faria LDB, Godoy WAC. Prey choice by facultative predator larvae of Chrysomya albiceps (Diptera: Calliphoridae). Mem Inst Oswaldo Cruz 2001; 96: 875-8. [CrossRef]

17. Wang Y, Yang JB, Wang JF, Li LL, Wang M, Yang LJ, et al. Development of the forensically important beetle Creophilus maxillosus (Coleoptera: Staphylinidae) at constant temperatures. J Med Entomol 2017; 54: 281-9.

18. Frątczak K, Matuszewski S. Instar determination in forensically useful beetles Necrodes littoralis (Silphidae) and Creophilus maxillosus (Staphylinidae). Forensic Sci Int 2014; 241(Suppl C): 20-6. [CrossRef]

19. Greene G. Rearing techniques for Creophilus maxillosus (Coleoptera: Staphylinidae), a predator of fly larvae in cattle feedlots. J Econ Entomol 1996; 89: 848-51. [CrossRef]

20. Lefebvre F, Gaudry E. Forensic entomology: a new hypothesis for the chronological succession pattern of necrophagous insect on human corpses. Annales de la Société entomologique de France (NS) 2009; 45: 377-92. [CrossRef]

21. Carter D, Tibbett M. Cadaver decomposition and soil:Processes. Tibbett M, Carter D, editors. Boca Raton, USA: CRC Press; 2008. [CrossRef]

22. Merritt R, Snider R, De Jong J, Benbow M, Kimbirauskas R, Kolar R. Collembola of the grave: A cold case history involving arthropods 28 years after death. J Forensic Sci 2007; 52: 1359-61. [CrossRef]

23. Anderson $G$, van Laerhoven $S$. Initial studies on insect succession on carrion in Southwestern British Columbia. J Forensic Sci 1996; 41: 617-25. [CrossRef] 